Information for citation:

Serova O. A., Kitsay Yu. A. Razgosudarstvlenie sotsial'noy sfery i problemy realizatsii kontseptsii predprinimatel'skogo universiteta v Rossii [Denationalization of the Social Sphere and the Problems of Implementing the Concept of Entrepreneurial University in Russia]. Vestnik Permskogo Universiteta. Juridicheskie Nauki - Perm University Herald. Juridical Sciences. 2017. Issue 38. Pp. 400-416. (In Russ.). DOI: 10.17072/1995-4190-2017-38-400-416.

UDC 347.12

DOI: 10.17072/1995-4190-2017-38-400-416

\title{
DENATIONALIZATION OF THE SOCIAL SPHERE AND THE PROBLEMS OF IMPLEMENTING THE CONCEPT OF ENTREPRENEURIAL UNIVERSITY IN RUSSIA
}

\section{O. A. Serova}

Immanuel Kant Baltic Federal University

14, Nevskogo st., Kaliningrad, 236016, Russia

ORCID: 0000-0002-3550-8838

ResearcherID: I-7706-2016

Articles in DB "Scopus" / "Web of Science"

DOI: $10.17072 / 1995-4190-2016-33-268-280$

e-mail: OlgSerova@kantiana.ru

\section{Yu. A. Kitsay}

Immanuel Kant Baltic Federal University 14, Nevskogo st., Kaliningrad, 236016, Russia

ORCID: 0000-0003-0945-0465

ResearcherID: E-7468-2017

e-mail: Juliana_kn666@mail.ru

Introduction: the system of higher education is undergoing a fundamental transformation aimed at the introduction of the Entrepreneurial University concept - University 3.0. This process involves changes in the basic approaches to both the internal administration of higher education institutions (HEIs) and their external environment (relations with the state, regional authorities, business community, and international partners). The Entrepreneurial University concept has been developed in the course of a large-scale reform oriented towards denationalization of the social sphere. Purpose: to establish the need for denationalization in higher education and identify the main tools for achieving its goals. Methods: the authors conduct a comparative analysis of economic and legal approaches to denationalization. They apply a system approach to identify the main parties involved in social reforms and determine the effect of political and legal decisions. Results: the authors formulate the requirements to the process of denationalization of universities and prove the inexpediency of changing the form of ownership of public universities. Conclusions: Russian academic community in general does not recognize or support the Entrepreneurial University concept, already introduced into some Russian universities, as many of the community's members feel reluctant to become more entrepreneurial. Nevertheless, innovation activities can enhance the competitiveness of Russian universities and help them to overcome their financial, human resources and other constraints. The social university concept is to be implemented as a part of corporate social responsibility to minimize the risk of abandoning the key mission of educational institutions.

Keywords: denationalization; privatization; social sphere; government agencies; entrepreneurial university; academic entrepreneurship 
Information in Russian

\section{РАЗГОСУДАРСТВЛЕНИЕ СОЦИАЛЬНОЙ СФЕРЫ И ПРОБЛЕМЫ РЕАЛИЗАЦИИ КОНЦЕПЦИИ ПРЕДПРИНИМАТЕЛЬСКОГО УНИВЕРСИТЕТА В РОССИИ}

\section{O. А. Серова}

Доктор юридических наук, профессор, зав. кафедрой гражданского права и процесса Балтийский федеральный университет имени И. Канта 236016, Россия, г. Калининград, ул. А. Невского, 14

ORCID: 0000-0002-3550-8838

ResearcherID: I-7706-2016

Статьи в БД «Scopus» / «Web of Science»:

DOI: $10.17072 / 1995-4190-2016-33-268-280$

e-mail: OlgSerova@kantiana.ru

\section{Ю. А. Кицай}

Кандидат юридических наук, доцент, доцент кафедры гражданского права и процесса Балтийский федеральный университет имени И. Канта,

236016, Россия, г. Калининград, ул. А. Невского, 14

ORCID: 0000-0003-0945-0465

ResearcherID: E-7468-2017

e-mail: Juliana_kn666@mail.ru

Введение: изменения в системе высшего образования ориентированы на реализацию концеепци предпринимательского университета. Данная концепция предполагает изменение основных подходов как к организации внутренней деятельности выстих учебных заведений, так и к взаимодействию с иными субъектами (государством, региональными властями, бизнесом, зарубежными партнерами). Концепџия предпринимательского университета (Университет 3.0) связана с общей реформой социальной сферь, ориентированной на прочесс ее разгосударствления. Цель: определить потребность разгосударствления в сфере высшего образования и основные формы достижения ее целей. Методы: проведен сопоставительный анализ экономических и правовых подходов к процессу разгосударствления. Использован системный подход для определения основных субъектов, участвующих в процессе реформирования сочиальной сферы, выявления последствий принимаемых политико-правовых решений. Результаты: сформулированы требования к процессу разгосударствления университетов, обосновано отсутствие необходимости изменения формы собственности государственных университетов. Выводы: кониепция предпринимательского университета, фактически реализуемая в российских университетах, не находит признания и поддержки в академической среде, многие представители которого не стремятся к повышению предпринимательской активности. Тем не менее участие университетов в инновационной деятельности позволит вузам успешно конкурировать в образовательном пространстве и преодолевать финансовые, кадровые и иные ограничения. Реализаџия концепции социального университета должна осуществляться в рамках сочиильно ответственной деятельности высшей иколь, с целью минимизации риска «отхода» от основной миссии образовательных организаций.

Ключевые слова: разгосударствление; приватизация; социальная сфера; государственные учреждения; предпринимательский университет; академическое предпринимательство 


\section{Introduction}

The new socio-economic reality calls for new approaches to economic and social development, for new types of communication between the state, the society and the business community as "a crucial condition for the generation of new meanings, ideas and projects" [8].

The system of social relations is undergoing significant changes. First of all, the social sphere is increasingly understood in its broad definition as all the processes, phenomena and socio-economic areas that are important for the quality of life, social and overall well-being of an individual [10]. The above-stated objective as well as the strategic goal of a state, which is the innovative economic development, can be achieved through new legal mechanisms providing not only a balance of private and public interests but also the possibility for an increase in efficiency in the resource-constrained environment. It is beyond question that the political institutions both in Russia and other countries have a considerable influence on the establishment of the main parameters for the ongoing reforms, on the choice of methods, and on the development of key performance indicators. However, as some researchers rightly note, the range of options is limited to "competitive market measures or nonmarket mechanisms involving the network of interacting agents within the framework of "the coordinated market economy" [28, pp. 5-6].

The social reform in Russia is implemented through the coordinated action of all subjects, i.e. it follows the second path of development. At the same time, the elements of market mechanisms are also introduced. They, in turn, require greater freedom and initiative for all the providers of social services.

Being the principal implementing agents for priority innovative development projects, universities could serve as the basis for identification of the main legal and organizational problems reducing the effectiveness of the reform or hindering the achievement of its objectives. It should be noted that the study does not cover the "Administrative" classification of universities. The university was viewed as a conditional model having historical and ontological grounds $[9$, p. 19.]

\section{Denationalization of the Social Sphere:}

\section{Concept, Signs, Legal and Regulatory Issues}

The social sphere has undergone significant changes and modernization in recent years. Initially, social services, i.e. assistance to disadvantaged citizens, were provided by competent government authorities or agencies. Recently, there have been systematic attempts to "restructure" the social sector using legal mechanisms inherent in the market environment [14]. New providers of social services, nonprofit organizations, can successfully compete with traditional state institutions.

However, the concept of the social sphere has substantially expanded. It now includes all areas of public life associated with the quality of life: culture, education, health, housing and utility, etc. Despite significant differences in the economic and social nature of these types of activities, they are all subject to similar legal regulations typical of the transition of economic relations to market mechanisms, including competition.

Traditionally, the main competing economic entities are private ones. In the social sphere, the proportion of state institutions has always been significant. The reasons for this include the fact the provision of social services traditionally was exclusively the prerogative of the state, the problems with private funding, non-profit organizations' lack of steady sources of income, and low paying capacity of the population.

However, the development of competition in the social service market involves the emergence of private entities either entering socially important markets independently or appearing as a result of denationalization of public services, as experts have never ruled out this possibility. 
Supporters of denationalization of the social sphere present a sufficient number of arguments in favor of this idea. It is believed that "citizens involvement in solving their own problems will allow eliminating welfare dependency mentality, increasing their responsibility both for their own lives and for the lives of people living next to them, and fostering active citizenship" [26]. However, in our opinion, this line of reasoning takes into account only the social significance of the social sphere modernization, leaving economic consequences and possible risks of transition to new mechanisms out. This approach undermines the credibility among the general public for the planned changes and puts many experts off these new ideas. However, one cannot agree with the opinion that "the problems of privatization are among the main factors hampering the reform process" [23, p. 94]. The analysis shows that the concept of denationalization as an organizational, legal and socio-economic phenomenon is much broader than the concept of privatization in terms of its content.

The issue of denationalization of the social sphere was raised at the beginning of the market transformation process in the country. It was understood as the change in the type of state and municipal institutions. The Ministry of Finances stated (for example in regards to the cultural sector) that in order to tackle this issue several others should be addressed. First of all, it was necessary to choose the best type of business organization for the objects in question, i. e. state institutions. Secondly, it was essential to identify all possible socioeconomic impacts of privatization and economic consequences of denationalization and to develop an effective constitutional rights protection system. Thirdly, it was important to determine the optimal ratio between state and municipal and nongovernmental institutions in the appropriate field ${ }^{1}$. The Ministry expressed this position in 1998. Back

\footnotetext{
${ }^{1}$ On denationalization of the social sphere: the letter of the Ministry of Finance of the Russian Federation No. 12-01-07 from 27.08.1998 [Electronic resource]. ATP "Consultantplus".
}

then, many legislative decisions had not been taken yet, and there was no awareness of the positive effect of the social sphere denationalization on either state, philistine or doctrinal level in terms of legal support of the process. The laws and regulations of the 1990's imposed a ban or a moratorium on privatization of virtually all public sector objects ${ }^{2}$.

The letter of the Ministry of Finance outlines the main risks associated with denationalization, including a significant increase in the cost of education, healthcare, and cultural services, a rise in the cost of health resort tours severely restricting the availability of these services to socially vulnerable groups; full or partial conversion of facilities ${ }^{3}$.

The idea of social institution privatization belonged to the Ministry of State Property of Russia, which considered it possible to nationalize them through the transformation of state and municipal institutions into joint-stock companies, which also did not conform to the then legislation ${ }^{4}$.

Since that idea of social institutions corporatization was discussed, the advantages of private non-profit organizations' operation in this field have become evident. It should be borne in mind that not all non-profit organizations show positive results. However, case analysis and spreading best practices in administration still make it possible to confidently state that non-profit institutions perform well in public sector. Services provided by private non-profit organizations are characterized by flexibility, technological and organizational effectiveness, prompt delivery, personified and targeted

\footnotetext{
${ }^{2}$ On the preservation of the status of state and municipal educational institutions and the moratorium on the privatization thereof: Federal Law No. 74-FZ from 16.05.1995 (repealed); Framework legislation of the Russian Federation on culture adopted by the Supreme Council of the Russian Federation no. 3612-1 from 09.10.1992 (ed. by 29.07.2017). Article 44 bans privatization of cultural values stored in state and municipal museums, archives and libraries, art galleries, etc., including premises and buildings where they are.

${ }^{3}$ On denationalization of the social sphere: the letter of the Ministry of Finance of the Russian Federation No. 12-01-07 from 27.08.1998.

${ }^{4}$ On denationalization of the social sphere: the letter of the Ministry of Finance of the Russian Federation No. 12-01-07 from 27.08.1998.
} 
assistance, innovativeness, application of new problem solving mechanisms; economic efficiency, minimization of administrative overhead costs, involvement of volunteers, uniqueness of programs, zero duplication of state programs, etc. [2]. High performance results delivered by many nonprofit organizations enable them to participate in social entrepreneurship projects and to occupy a fairly stable position in regional socially important markets.

In recent years, the idea of denationalization of the social sphere has become relevant again. However, the implementation of this initiative is gradual as it takes a while to prepare the necessary regulatory and legal framework and to prepare the public, the media, and experts for this decision. The beginning of this process must be linked to the changes in types of state and municipal institutions $^{1}$ and the emergence of autonomous institutions $^{2}$ in 2006.

However, the term denationalization has no direct relation to the notion of privatization at the moment. Sometimes it is associated with commercialization, including the commercialization of state and municipal institutions' activities. The term can also be interpreted narrowly as a public sector project work or an expansion of opportunities for non-profit organizations to access public procurement system and to join social service provision system [7].

Some authors consider the term to be tightly linked to the notion of "socially-oriented non-profit organizations" [27]. In this context, denationalization does not involve changes in the organizational and legal form of existing state and municipal institutions instead it presupposes non-profit organizations' access to the social services market. Thus,

\footnotetext{
${ }^{1}$ On changes in the legislative acts of the Russian Federation in connection with adoption of the Federal law "On autonomous institutions" and clarification of the legal capacity of state and municipal institutions: the Federal law No. 175-FZ from 03.11.2006. Collected Legislation of the Russian Federation. 2006. No. 45. Article 4627.

${ }^{2}$ On autonomous institutions: the Federal law No. 174-FZ from 03.11.2006. Collected Legislation of the Russian Federation. 2006. No. 45. Article 4626.
}

this type of denationalization does not imply the change in the form of ownership. Hence, the goals of denationalization can be achieved only after the determination of the optimal ratio between state institutions and private legal entities required in a relevant market and the establishment of the control over the service quality regardless of the organizational and legal form of the service providers.

As it has already been indicated, the intended changes cannot be effective without the comprehensive analysis of the denationalization process highlighting not only the positive objectives and results but also potential risks in order to minimize them. As in the late 1990's, many experts believe that the commercialization of public services will have the following negative consequences:

- growing social tension;

- reduced availability of educational, medical, and social services;

- lack of effective results of previous economic reforms [11, p. 176].

It should be noted that there are other negative aspects, including the lack of financial sustainability and the shortage of highly qualified permanent staff in non-profit organizations. With few exceptions, most non-profit organizations are unable to provide services to the population without subsidies, neither can the population afford many of the services. According to experts, it is the instability of the social services market that results in a shortterm nature of non-profit organizations' [2]. This makes them uncompetitive. As these organizations are unable to operate without grants or state support, they cannot be considered sufficiently stable and capable of performing state functions related to social services provision.

Some experts claim that commercialization itself is a potential negative consequence of denationalization [19]. In our opinion, commercialization of the public sphere observed in the recent decades was not a result of any government decisions but was brought about by overall economic and social situation. 
Experts anticipate the loss of public property, the loss of integrity and unity, i. e. the consistency of the public sector [23, p. 94]. In this regard, it is proposed to restructure state-financed welfare institutions without the privatization of state and municipal property and associated loss of sectoral manageability through subject-object division [23, p. 94]. The subject becomes private, the property remains in public ownership. In fact, this approach was adopted to create autonomous institutions intended to be more independent in terms of making economic decisions, to use funds effectively and to attract extra funding. The establishment of autonomous institutions was viewed as a stage of forthcoming privatization of state institutions' property. However, autonomous institutions retained the legal status of state and municipal institutions, because perhaps otherwise the above-listed risks could not be avoided.

Denationalization of public services involves another important element that is not associated with privatization meaning the change in the form of ownership. It is the delegation of governmental authority to private organizations. Our country has already seen such redistribution of state functions and the emergence of private-public legal entities, e. g. state-owned corporations and enterprises and public-law companies $[20 ; 21]$. This approach to denationalization of public services requires addressing not only the issue of service quality but also the issue of service standards establishment. The non-profit sector is sceptical about the abolition of licensing or, for example, the absence of a certification mechanism. It is concluded that none of the quality control mechanisms works [25]. At the same time, both entrepreneurial and selfregulation practices prove that the idea of a market providing quality assurance independently is reckless. If the state transfers specific functions to private entities, such entities have to establish a single set of rules governing the provision of social assistance and services in compliance with the goals and objectives the state has as the guarantor of the pro- vision of these services to its citizens. At the same time, many representatives of the non-profit sector are well aware of these risks and problems and claim that the procedure is not formalized, that the registration standards are missing, and that the officials are not inclined to pursue transformations (risks according to NGO polls) [19]. Even the disagreement on the scope of the term proves the doubts to be reasonable. Furthermore, it is pointed out that "the initiatives of recent years involved only extensive redistribution of subsidies and were not in any way related to the fundamentals of these systems' design and operation" [11, p. 176]. This conclusion is pivotal for the study since any legislative changes in the social sphere should have been based on a clear strategic vision not only providing the reasoning for the changes but also setting up the roadmap for their introduction. Under our conditions, even though the ideas were transformed into some conceptual decisions, the implementation leaves a lot to be desired. An illustrative example of this is the introduction of the concept of "non-profit providers of public services" not properly linked with the notion of a non-profit social enterprise $[15$, p. 73$]$. Furthermore, the majority of changes did not fall into the framework of the systematic development of civil law, and this did not help to clarify the rationale for the legal decisions made.

The legal status of state and municipal institutions engaged in the social sphere also requires an integrated approach. From a civil law perspective, the legal status of these organizations allows to classify them as economic entities. Scholars of the other branches of law, on the contrary, believe that "state-funded institutions of the social sphere are not a part of the mechanism of the state, as they are not government agencies. Neither can they be considered to be economic entities, as they remain in the system of administrative subordination and spending caps peculiar to the mechanism of the state" [23, p. 94]. This is just one of the possible views on the nature of state institutions in modern Russia. Many of them combine the status of both 
state bodies and economic entities, being within the scope of budgetary, civil, administrative, and business law concurrently. However, the compliance of this approach to the provisions of the current legislation is disputable.

The redistribution of powers between state bodies and authorized legal entities cannot solve acute social and economic problems, either from the standpoint of denationalization or ensuring competition in the socially important markets. It is obvious, that the types of activity included in the concept of a socially important market are quite diverse and differ in many ways. A representative example of this is housing and utilities included by many experts into both socially important markets and social services.

There were more reasons to denationalize housing and utilities than any other sector, e. g. education, culture, museums. They include sufficient financial provision for the operation of organizations in this sector, income-generating opportunities, and the inability of citizens to stop using a large proportion of housing and utility services. However, the practice shows that the quality of these services is fairly low, there are constant conflicts between management companies and owners of living accommodation, and there are a considerable number of fraud and corruption incidents. In other words, the significant presence of private entities in housing and utility sector did not foster the competition.

It is held that innovations in the housing sector are based on the effective division of functions between the owners of housing (organizations authorized to represent the owners, management organizations) and the maintenance providers, as well as on their effective contractual relationships [12, pp. 4243]. Thus, neither the legal status of entities nor the form of ownership is crucial for the development of competition in socially important markets. The foundation for competitiveness is the quality of management and the efficiency of legal means.

The denationalization of the socially important markets is linked to the development of competi- tion. How do we define the competition? Is it receiving state support on a priority basis? Or is it offering a better service than any other provider in the market? It stands to mention that the key factor in service provision is not the need but the demand, i. e. the need for certain services associated not so much with the desire to acquire them but with the ability to do, the willingness to pay a certain price for it [10]. Naturally, the characteristic feature of many sectors of the social sphere is the limited resources of potential customers. However, the social sphere, as well as the nonprofit sector, has always operated in the limited resources environment. Competitiveness for nonprofit organizations is related, first of all, to their ability to manage these resources, both debt and equity ones [10]. Thus, it is associated with special managerial competencies, administrative innovations, and the ability to follow best practices. In this context, statements that "the existing regulatory framework formally allowing non-governmental organizations to enter the markets of family and children's services does not ensure equal operating conditions for all the market players including state and municipal institutions" seem not completely accurate [25]. However, it is difficult to provide equal conditions with regard to what this equality means. If it is the admission to budgetary resources, it is impossible to achieve it. The equality can only be achieved through the access to the information on service providers and service description, free entry to the services market, and granting the right of option to all the customers [10].

Positive performance results of non-profit organizations in the social sphere and their analysis allow us to conclude that the objectives of developing competition between non-profit organizations are contradictory. On the one hand, the state seeks competition in the social sphere, keeping the functions of a customer and of a quality controller. At the moment, only the state can guarantee the provision of expensive social services [22]. The clear illustration of this is the field of medical technology, 
scientific research, etc. As for the secondary and higher education, the track record of non-state universities allows saying that under certain conditions they can successfully compete with public HEIs. Thus, effective state educational institutions can seek denationalization, for example by means of corporatization, since in this case, the advantages of changing the legal status are clear. For this particular reason, the reform changing types of state and municipal institutions was not completed. In these terms, Russia follows the same patterns as those observed in other countries, that is as professional non-profit organizations develop, they drift towards profit organizations [10].

Thus, summing up the intermediate results of the study, we can conclude that the denationalization of the social sphere takes several forms, none of them related to the change in the form of ownership, which does not allow us to equate denationalization with privatization. This way the government not only maintains a fairly high level of control over the property transferred to state organizations in the social sphere but also takes an active part in the strategic development of certain fields of social activity associated with the social sphere.

\section{Universities as Centers}

\section{for Academic Entrepreneurship and Competition Development}

As it has already been noted, the term "social sphere" in its broad definition includes education. The priority project "Universities as innovation centers" gives substantial evidence of remarkable efforts the state makes to ensure modernization and innovative development of the economy. Universities should become major centers for the regional socio-economic development particularly in the sphere of innovative development. However, the legal support of the processes under consideration, in our opinion, leaves out the peculiarities of the

\footnotetext{
${ }^{1}$ Passport of the "Universities as innovation centers" priority project adopted by the Presidium of the Presidential Council for Strategic Development and Priority Projects. Available at: e-journal.spa.msu.ru (accessed 15.02.2017)
}

university's traditional legal status of a public institution. In the implemented reforms, there is no clear connection between the legal status of the property, the peculiarities of the management system of similar organizations, and the goals and objectives. Furthermore, there is no unified definition of the academic or scientific entrepreneurship and the commercialization of the university research. Despite the active use of these terms, the lack of legal and doctrinal conceptual framework has a negative effect on the development of the statutory regulation, and on the introduction of relevant practices into the higher education system.

Attempts to bridge the gap with the developed countries and to reach the required indicators of the country's technological development in a short time frame are perceived as strategic tasks requiring a political-economic solution. This is the reason for the conflict between doctrinal civil approaches and the practical implementation of new initiatives.

The main goal of the University 3.0 concept is to create an integrated entrepreneurial ecosystem with universities being the key providers of innovation. Universities are to become the city-forming centers of regional economic clusters and to act as economic agents, subjects with the main goals of managing IP assets and exercising considerable influence over new markets [17]. At the same time, many Russian universities' development objectives are defined as regional, despite the fact that most of them preserved the status of federal subjects. "It is important for Russia not only to create but also to innovate, that is to turn the inventions into commercially successful projects and thus to benefit the society" [13]. For the majority of universities in the constituent entities of the Russian Federation, such projects are associated with the implementation of regional projects.

Universities are required to generate entrepreneurial activity in the sphere of innovations, to develop technological entrepreneurship, to form new markets, that is, to forecast economic changes and 
determine the main future parameters of the economy. However, the current legal framework for the legal status of HEIs in the Russian Federation does not adhere to these objectives. Moreover, due to a rather complex organizational and management structure, many universities face difficulties when they interact with the business community in the capacity of a potential performer of R\&D or a seller of licenses [17]. Effectiveness and efficiency of specialized organizations providing services on research commercialization are higher than that of many universities.

Since the overwhelming majority of Russian universities engaged in innovative activities are state-owned, it is necessary to elaborate the procedure for the interaction between universities, the academic community, and innovative organizations founded by universities, as well as the requirements to the systems of management and control over the operation of business entities and partnerships where a university has a share in the authorized (joint) capital.

The vast majority of universities involved in the priority project for the development of innovative activity are state institutions. Being non-profit unitary organizations, these HEIs cannot become business entities. The notion of income-generating activities introduced by Article 50 of the Civil Code of the Russian Federation is in contradiction with the idea of universities being agents for academic entrepreneurship. Traditional income-generating activities of universities are either directly related to their core activities, e. g. the provision of paid educational services, or are ancillary ones, including premises lease, R\&D works for third parties, expert evaluation, etc. This approach is based on conventional ideas of the university's place in the business environment according to which, universities participate in research commercialization and interact with economic entities, but they are not business entities.
The change in the regulatory status will allow modern universities to develop an effective legal model tailored to the needs of the economy. University entrepreneurship is seen today as a major economic factor. The focus is on the creation of companies, as this is one of the main means of research commercialization [31]. Characteristic features of University 3.0 are entrepreneurial competencies and establishment of small innovative enterprises and subsidiaries as the basis for innovation.

The idea of the university's company is not original. However, we could not find a Russian study highlighting systemic issues faced by such organizations and their founders. While international studies identify these problems. One of them is the lack of investments at the early stages of the development of a university spinoff (a company established by a university around a technological innovation) [34]. The studies indicate two models for university research commercialization. One of them involves only researchers, i. e. academic entrepreneurs, and, the other one presupposes the attraction of external entrepreneurs, i. e. private investors [34]. The studies provide a number of distinguishing features of these models. In our conditions, there is a need for additional research, since both Russian legislation and established practice can alter these features. For example, in our opinion, the need for government funding is characteristic of both models, as universities' investors are in a certain sense oriented to the state support for priority research projects.

The international term "academic entrepreneurship" does not coincide with the Russian one used in the legal field [30]. The term does not fit the traditional definition of the entrepreneurial activity as "a type of economic activity carried out by an entrepreneur at its own risk in those areas of economic activity and in the ways that in his 
opinion provide him with a victory in the competition and allow him to obtain maximum profit" $[18$, p. 89]. The mission of the university does not allow it to seek only profit even within the framework of academic entrepreneurship.

In addition to the direct faculty involvement in business companies' activities and establishment, academic entrepreneurship includes the transfer of technology and knowledge. The term "scientific entrepreneurship" has a similar meaning. It is related to the increase in the university's importance in the innovation achieved through the changes in the interaction between business and science, transfer of technologies, and bringing inventions to the market. This concept focuses on radical technological innovations with significant economic impact [33]. The scopes of "academic entrepreneurship" and "scientific entrepreneurship" are similar, thus there is no need to make a fundamental distinction between them. The only difference is that the term "academic entrepreneurship" describes a greater degree of connection between the entrepreneurial activity with other functions of the university researchers, that is, training and education.

According to economists, the new role of universities is a result of the transition to a postindustrial society. "The sixth technological order will be characterized by the development of robotics, biotechnology based on the achievements of molecular biology and genetic engineering, nanotechnology, artificial intelligence systems, global information networks, integrated high-speed transport systems" [1, p. 160]. Not only have universities a significant number of researchers already involved in these areas but also they can use the intellectual potential of undergraduate and postgraduate students to promote their projects, which may not be in demand only because of poor communication with the business community and investors.

In this new paradigm of the mission realization, the university shall not only facilitate the interaction of researchers and business and industry.
According to B. R. Clark, the key feature of the Entrepreneurial University is not only the aspiration for innovation but also risk-taking in new practices with unclear results [5, p. 144]. These risks can be associated with the lack of positive research results, costs of industrialization of research and development, etc. Given the special civil liability regime of state institutions, it is impossible to put the idea of the Entrepreneurial University into practice without significant changes in the legal status.

The idea of the Entrepreneurial University is widely associated with the commercialization of research [5, p. 145]. "Unlike classical universities, entrepreneurial universities combine teaching, research and entrepreneurial activities and receive income from it, and have innovation infrastructure objects" [4]. In our opinion, this interpretation significantly limits the initially formed concept, as it negates the importance of entrepreneurial activity of the university as an economic entity. Their proactive stance is in fact associated with increased responsibility for their own activities. Russian theorists of the Entrepreneurial University note that "this is a higher educational institution making systematic efforts to overcome constraints in three areas, including knowledge generation, teaching, and transformation of knowledge into practice, by initiating new activities, transforming the internal environment, and modifying the interaction with the external environment" [16, p. 55]. This approach also indicates the need for changes in the legal status of universities and the development of new legal and institutional and administrative models adherent to a new HEI's mission in the context of transition to the innovation economy [6].

International experience shows that "in developed countries, most scientific institutions, as well as medium-sized businesses, are privately owned sometimes by the same legal entities or private individuals" [3, p. 28]. It is clear that the creation of such an institutional infrastructure for transformation is impossible in Russia due to the lack of time, the considerable scale of the planned changes and the goals of innovative economic development. 
Despite the declared adherence to the values of the market economy, in terms of bridging the substantial technological gap between Russia and the leading countries, the state looks up to the controlled organizations whose activities are related to the implementation of the decisions of the authorized institutions. A private initiative is good, but government-controlled legal entities seem more promising for the achievement of major goals. However, the fulfillment of the objectives in the innovative spheres, as already noted, requires a special legal regime for property owned by these legal entities and respect for the interests of all persons involved in innovation development. "In Russia, the conflict of property interests vitiates the efforts to form an innovative climate in the country" [3, p. 28]. This means that denationalization must also affect the higher education to some extent.

The need for denationalization is associated with the need to increase the economic independence of universities, since "in a cognitive society, universities themselves become the most important generators of ideas, knowledge, technologies, innovations. They do not fulfil the orders of other entities, instead, they actively promote their own products that can outrun current needs, create new activities, new needs and markets" [9, p. 26]. At the same time, both international and Russian experts correctly point out that the university engagement in entrepreneurship can have a negative impact due to the fact that material and human resources are limited and the combination of the traditional function and entrepreneurial activities is nonoptimal. However, resource constraints are universal, as all the spheres of economy, including traditional business, suffer from them. These general limitations include personnel qualifications, lack of finance, infrastructural, institutional, and other restrictions [30]. Given the similarity of the way the role of universities is changing across the world, it is vital to realize that changes are unavoidable, and the restrictions do not form the justification for abandoning the objectives.

Denationalization of higher education can be implemented in Russia only through the expansion of the authority of the university administration and by increasing its influence in a relevant region. The former system of higher education was targeted at solving state problems and was subordinate to the federal sector. However, under the current conditions, the interaction between the university and the region should become closer, thus the university administration should enjoy independence in their actions and decisions.

Denationalization is also implemented through the establishment of virtually corporate organizational structures, as universities include infrastructure created within the framework of various investment projects, e. g. tourist and sports facilities, companies formed with the participation of the university, research laboratories created within the public-private partnership. It is inexpedient to retain the state ownership of all the objects related to innovative development. It is quite difficult for a state institution to cover all the maintenance and operating expenses. Equity participation by other companies and other forms of management and control seem more advantageous.

Denationalization can be seen as an abolition of state monopoly, the development of the mixed economy, and the state withdrawal from direct economic management [24, p. 235]. However, we proceed from the assumption that this result is usually associated with privatization. Denationalization of higher education can take place without a change of ownership, being actually "decentralization of government property administration” [24, p. 235].

This type of denationalization does not involve the loss of control by the state. Moreover, in most countries, universities usually belong to the public sector. They are obliged to follow the policy of the government [29]. This is applicable to virtually all the countries. The trend for the reduction of public funding for science and higher education and stimulation of the entrepreneurial activity of the university leads to toughening up of the requirements to economic effectiveness and the quality of university management [29]. At the same time, J. Christopher singled out several other factors affecting university management paradigms, including the influence of regional authorities, financial organizations, 
and industry, global competition involving not only the struggle for students, faculty mobility, but also international partner' influence on the process of decision-making at both state and university level; the impact of university culture, considerable autonomy; professionalism of the university internal management, the need to use approaches that are more characteristic of corporate practice [29].

The influence and evidence of these trends in Russia are growing. However, there are significant differences, for example, regional authorities cannot determine the regulatory conditions for educational and academic activities of the university. Interaction is carried out within the framework of general agreements without the legalization of certain forms of support.

Undoubtedly, the new social role of universities requires a change in doctrinal ideas of their organizational and management structure, the limits of their special legal capacity, and the expansion of their powers in terms of property management. The absence of the full status of the owner and the fact that the university property belongs to the Russian Federation makes it difficult to resolve a number of issues, such as the conclusion of investment contracts with private individuals and subjects of the Russian Federation. Scholars of civil jurisprudence have been expressing similar ideas of the inconsistency of the legal status of non-owner with modern economic realities. Interaction with the adherents of the University 3.0 concept would accelerate the reform of the system legal entities, excluding those conforming to the country's former economic structure.

The exclusive use of legal and institutional tools does not allow for the development of the innovation economy and the increase in the university's importance in these terms. K. J. Holloway systematized the problems of the academic community arising from the need to adapt to the commercialization of science and universities being the key mission of the neo-liberal economy. The author reaches the conclusion that commercialization is becoming the norm, but not all faculty members are ready to accept it [32]. Russian universities must consider this. The research results reveal the international differences in the evaluation of "academic entrepreneurship". For example, British scientists incline to the traditional idea of the social role of the university, while Chinese researchers welcome the strengthening of entrepreneurship in the academic university environment [37, pp. 776-777].

Without the support of the academic community and their general recognition of the need for change in higher education, the management decisions and the measures taken to adopt new approaches to the organization of training and research cannot be sufficiently effective. Practice shows that the university community does not fully support the initiatives related to the University 3.0 concept. The reasons are the lack of information, the reluctance to change the established principles of their own research activities, the perception of entrepreneurship as a manifestation of cupidity, and the concerns that academic entrepreneurship will supersede the university's main mission. One of the often-used illustrations of this point is the change of higher education expenditures. There is an opinion that all the efforts are devoted to the expansion of infrastructure, purchase of high-priced laboratory equipment, and creation of comfortable campuses [36], while the incomes of most teaching staff, especially those not engaged in innovative research, do not change.

Thus, only the modernization of the management system and organizational structure of the university and the cultural changes in the academic environment can allow implementing the state strategic plans to increase the competitiveness of Russian universities.

\section{Conclusions}

Foreign authors are not unanimous in the view about the significance and positive nature of the Entrepreneurial University concept. There is an opinion that the role of universities in the creation of innovations is overestimated, and this activity is not their main function. It is believed that the 
traditional model of the university aimed at specialist training should remain the priority mission of universities [35]. Russian higher education community holds similar views.

However, in the context of the social reforms and denationalization, the University 3.0 concept allows us to conclude that the tasks are systematically unified. Involvement in the innovative development of the regions along with the successful commercialization of research allows universities to compete effectively on both the external and internal education markets and to ensure the financial stability of higher education. It stands to reason that some authors believe that University 3.0 should be thought of as a socially responsible university [13], whose mission is to solve socio-economic problems of the society and the country.

\section{References}

1. Averbukh V.M. Shestoy tekhnologicheskiy uklad i perspektivy Rossii (kratkiy obzor) [The Sixth Technological Setup and Perspectives of Russia (Abstract)]. Vestnik Stavropol'skogo gosudarstvennogo universiteta - Bulletin of the Stavropol State University. 2010. Issue 71. Pp. 159-166. (In Russ.).

2. Avrorina L. V. Rossiya: Nekommercheskie organizatsii kak osobyy segment rynka sotsial'nykh uslug [Russia: Non-Profit Organizations as a Special Segment of the Social Services Market]. Vklad negosudarstvennykh nekommercheskikh organizatsiy $v$ reshenie sotsial'nykh problem $v$ Rossii. Razvitie sotsial'nykh uslug. Sbornik statey i materialov «mozgovogo shturma»; pod red. O. B. Kazakova [Contribution of NGOs to Solving Social Problems in Russia. Development of Social Services. Collection of Articles and Materials of "Brainstorming"; ed. by O. B. Kazakova]. Available at: http://www.civisbook.ru/files/ File/ngos contribute.pdf (accessed 07.09.2017). (In Russ.).

3. Andreeva M. E. Tekhnologicheskie uklady sovremennoy ekonomiki. Elektronnoe tekstovoe izdanie; nauch. red. S. V. Kortov [Technological Structures of the Modern Economy. E-text edition; ed. by S. V. Kortov]. Ekaterinburg, 2016. (In Russ.).

4. Andryushkevich O., Denisova I. Opyt funktsionirovaniya predprinimatel'skikh universitetov $v$ kontekste modeli "troynoy spirali" [Operational Experience of Entrepreneurial Univer- sities in the Context of the Model of "Triple Helix"]. Available at: http://www.kapital-rus.ru (accessed 21.04.2017). (In Russ.).

5. Bunyak N. M. Predprinimatel'skiy universitet: sushchnost' i osobennosti formirovaniya [Entrepreneurial University: Essence and Peculiarities of Formation]. Juvenis scientia. 2016. Issue 2. Pp. 144-147. (In Russ.).

6. Demidov M. Novye vozmozhnosti: chto mozhet dat' biznes vuzam? [New Opportunities: What Can Business Give Universities?]. Available at: http://www.4science.ru/articles/Novaya-nishabiznes-vusam (In Russ.).

7. Eferina T. V., Lizunova V. O., Prosyanyuk D. V. Mekhanizmy povysheniya kachestva sotsial'nykh uslug: razgosudarstvlenie sfery sotsial'nogo obsluzhivaniya naseleniya [Mechanisms to Improve the Quality of Social Services: Privatization of Social Sphere]. Available at: http://ac.gov.ru/files/content/1828/statya-eferinalizunova-prosyanyuk-2-red-pdf.pdf (accessed 09.09.2017). (In Russ.).

8. Efimov V.S., Lapteva A. V. Universitet v situatsii postindustrial'nogo perekhoda: global'nye trendy $i$ vyzovy razvitiya. Universitet 4.0 [The University in the Situation of PostIndustrial Transition: Global Trends and Development Challenges. University 4.0]. Available at: www.slideshare.net/leuter_of strategic RnD/40-68989423. (In Russ.).

9. Efimov V.S., Lapteva A. V. Kognitivnyy universitet: kontury budushchego [Cognitive University: the Contours of the Future]. Universitetskoe upravlenie: praktika i analiz University Management: Practice and Analysis. 2014. Issue 6(94). Pp. 18-29. (In Russ.).

10. Zhogin B. G. Konkurentsiya v sfere sotsial'nykh uslug: preimushchestva i slabosti NKO [Competition in the Field of Social Services: Strengths and Weaknesses of Non-Profit Orgaizations]. Vklad negosudarstvennykh nekommercheskikh organizatsiy $v$ reshenie sotsial'nykh problem $v$ Rossii. Razvitie sotsial'nykh uslug. Sbornik statey $i$ materialov «mozgovogo shturma»; pod red. O. B. Kazakova [Contribution of NGOs to Solving Social Problems in Russia. Development of Social Services. Collection of Articles and Materials of "Brainstorming"; ed. by O. B. Kazakov]. Available at: http://www.civisbook.ru/files/ File/ngos_contribute.pdf (accessed 07.09.2017). (In Russ.).

11. Zaytsev D. V., Zaytseva O.V. Razgosudarstvlenie sotsial'noy sfery $v$ Rossii: sotsial'nopravovoy aspekt [Privatization of Social Sphere in Russia: Socio-Legal Aspect]. Obshchestvennye nauki i sovremennost' - Social Sciences 
and Contemporary World. 2007. Issue 3. Pp. 174-176. (In Russ.).

12. Iraeva N. G., Kalimullina E. R. Osobennosti realizatsii innovatsionnoy deyatel'nosti $v$ zhilishchno-kommunal'nom khozyaystve [Features of Implementation of Innovative Activity in the Housing and Communal Services]. Vestnik UGNTU. Nauka, obrazovanie, ekonomika. Seriya: Ekonomika - Proceedings of the Ufa State Petroleum Technical University. Science, Education, Economics. Series: Economics. 2014. Issue 4. Pp. 42-45. (In Russ.).

13. Itogovyy obzor po rezul'tatam uchastiya prepodavateley Sankt-Peterburgskogo gosudarstvennogo ekonomicheskogo universiteta $v$ XX Peterburgskom mezhdunarodnom ekonomicheskom forume, 16-18 iyunya $2016 \mathrm{~g}$. TThe Final Review of the Participation of the Professors of Saint Petersburg State University of Economics in the XX St. Petersburg International Economic Forum, June 16-18, 2016]. St. Petersburg, 2016. Available at: http://www.unecom.ru. (In Russ.).

14. Kitsay Yu. A. Pravovoe obespechenie konkurentosposobnosti negosudarstvennykh organizatsiy $v$ sotsial'noy sfere [Legal Support for the Competitiveness of Non-Governmental Organizations in the Social Sphere]. Moscow, 2016. 240 p. (In Russ.).

15. Kitsay Yu. A. Nekommercheskie organizatsii ispolniteli obshchestvenno poleznykh uslug: mnenie eksperta o proekte [Non-Profit Organizations Implementing Socially Beneficial Services: Expert Opinion on the Bill]. Ekonomika. Predprinimatel'stvo. Okruzhayushchaya sredaEconomics. Enterprise. Environment. 2016. Issue 2(66). Pp. 71-74. (In Russ.).

16. Konstantinov G. N., Filonovich S. R. Chto takoe predprinimatel'skiy universitet? [What is a Business-Oriented University?]. Voprosy obrazovaniya - Educational Studies. 2007. Issue 1. Pp. 49-63. (In Russ.).

17. Kuznetsov E. Universitet 3.0 v ekonomike znaniy [The University 3.0 in the Knowledge Economy]. Available at: http://www.izvestia. $\mathrm{ru} /$ news/650622. (In Russ.).

18. Ponomarev O. B. K voprosu ob upravlenii predprinimatel'skoy deyatel'nost'yu [On the Governance of Entrepreneurial Activity]. Vestnik Baltiyskogo federal'nogo universiteta im. I. Kanta. Seriya: Gumanitarnye $i$ obshchestvennye nauki - IKBFU's Vestnik: Humanities and Social Science. 2017. Issue 2. Pp. 82-91. (In Russ.).

19. Pushkina N. Sotsial'nye uslugi $v$ ispolnenii NKO - ozhidaniya i riski [Social Services in the Performance of Non-Profit Organizations:
Expectations and Risks]. Available at: https:// www.asi.org.ru/article/2013/09/18/sotsial-ny-euslugi-v-ispolnenii-nko-ozhidaniya-i-riski/ (accessed 07.09.2017). (In Russ.).

20. Serova O. A. Eshche raz o gosudarstvennykh korporatsiyakh ili o novykh zadachakh nauchnykh issledovaniy [Once Again on the Government Corporations or on the New Tasks of Scientific Research]. Vestnik Permskogo universiteta. Yuridicheskie nauki - Perm University Herald. Juridical Sciences. 2013. Issue 4. Pp. 325-330. (In Russ.).

21. Serova O. A. Pravo sobstvennosti publichnopravovykh kompaniy [The Right of Ownership of Public-Law Companies]. Zakony Rossii: opyt, analiz, praktika - Laws of Russia: Experience, Analysis, Practice. 2017. Issue 2. Pp. 15-21. (In Russ.).

22. Sotsial'nye predprinimateli na rynke sotsial'nykh uslug: perspektivy razvitiya [Social Entrepreneurs on the Market of Social Services: Prospects of Development]. 2016. Issue 2. 46 p. Available at: http://www.soc-invest.ru/wpcontent/uploads/2017/04/Брошюра-ФОМ.pdf (accessed 06.09.2017). (In Russ.).

23. Tikhomirov A. V. Razgosudarstvlenie uchrezhdeniy sotsial'noy sfery bez privatizatsii zakreplennogo za nimi imushchestva [Social Sphere Institutions Denationalization without Privatization of Bound State Property]. Biznes, menedzhment i pravo - Business, Management and Law. 2009. Issue 3. Pp. 94-95. (In Russ.).

24. Trifonov V.A. Privatizatsiya kak forma preobrazovaniya gosudarstvennoy sobstvennosti $v$ sovremennoy rossiyskoy ekonomike [Privatization as a Form of Transformation of State Property in the Modern Economy of Russia]. Vestnik KemGU - Bulletin of Kemerovo State University. 2014. Vol. 2. Issue 1. Pp. 235-240. (In Russ.).

25. Feoktistova E. N. Razvitie sotsial'nogo obsluzhivaniya $s$ uchastiem negosudarstvennogo sektora [Development of Social Services with the Participation of the Private Sector]. Vklad negosudarstvennykh nekommercheskikh organizatsiy $v$ reshenie sotsial'nykh problem $v$ Rossii. Razvitie sotsial'nykh uslug. Sbornik statey i materialov «mozgovogo shturma»; pod red. O. B. Kazakova [Contribution of NGOs to Solving Social Problems in Russia. Development of Social Services. Collection of Articles and Materials of "Brainstorming"; ed. by O. B. Kazakov]. Available at: http://www.civisbook.ru/files/File/ngos_contribute.pdf (accessed 07.09.2017). (In Russ.).

26. Khukhlina V.V. Razgosudarstvlenie rynka sotsial'nykh uslug $v$ ramkakh realizatsii $F Z$ 
No. 442 «Ob osnovakh sotsial'nogo obsluzhivaniya grazhdan $v$ Rossiyskoy Federatsii» [Privatization of the Social Services within the Framework of the Implementation of the Federal Law No. 442-FZ "On the Bases of Public Social Services in the Russian Federation"]. Available at: http://esa-conference.ru/wp-content/uploads/ files/pdf/Huhlina-Valentina-Vladimirovna.pdf (accessed 06.09.2017) (In Russ.).

27. Yakusheva F. Razgosudarstvlenie sotsial'noy sfery: pervye shagi [Denationalization of the Social Sphere: the First Steps]. Available at: http://rt-online.ru/razgosudarstvlenie-sotsialnoj-sfery-pervye-shagi/ (accessed 07.09.2017). (In Russ.).

28. Broberg J. C., McKelvie A., Short J. C., Ketchen D. J. (Jr.), Wan W. P. Political Institutional Structure Influences on Innovative Activity. Journal of Business Research. 2013. Vol. 66. Issue 13. Pp. 2574-2580. (In Eng.) DOI: 10.1016/j.jbusres.2012.05.014.

29. Christopher J. Governance Paradigms of Public Universities: an International Comparative Study. Tertiary Education and Management. 2012. 17 September. Pp. 1-17. (In Eng.). DOI: 10.1080/ 13583883.2012.724705.

30. De Silva M. Academic Entrepreneurship and Traditional Academic Duties: Synergy or Rivalry? Studies in Higher Education. 2015. 17 April. Pp. 2169-2183. (In Eng.) DOI: 10.1080/03075079.2015.1029901.

31. Hayter C. S. Harnessing University Entrepreneurship for Economic Growth: Factors of Success among University Spin-Offs. Economic Development Quarterly. 2013. Vol. 27. No. 1. Pp. 18-28. (In Eng.). DOI: 10.1177/089 1242412471845.

32. Holloway K. J. Normalizing Complaint: Scientists and the Challenge of Commercialization. Science, Technology and Human Values. Cambridge (Mass.), 2015. Vol. 40. No. 5. Pp. 744-765. (In Eng.). DOI: 10.1177/0162243 915576004.

33. Menzies M. B. Researching Scientific Entrepreneurship in New Zealand. Science and Public Policy. 2012. Vol. 39. Pp. 39-59. (In Eng.). DOI: 10.3152/030234212X13214603531842.

34. Politis D., Gabrielsson J., Shveykina O. EarlyStage Finance and the Role of External Entrepreneurs in the Commercialization of University-Generated Knowledge. Venture Capital. 2012. Vol. 14. No. 2-3. Pp. 175-198. (In Eng.). DOI: 10.1080/13691066.2012.667905.

35. Rooij A. van. University Knowledge Production and Innovation: Getting a Grip. Minerva. 2014. Vol. 52. No. 2. Pp. 263-272. (In Eng.). DOI: $10.1007 / \mathrm{s} 11024-014-9254-1$.
36. Schejbal D. In Search of a New Paradigm for Higher Education. Innovative Higher Education. 2012. 6 March. Pp. 1-14. (In Eng.). DOI: 10.1007/s10755-012-9218-z.

37. Walsh E., Hargreaves C., Hillemann-Delaney U., Jizhen L. Doctoral Researchers' Views on Entrepreneurship: Ranging from "a Responsibility to Improve the Future" to "a Dirty Word". Studies in Higher Education. 2015. Vol. 40. No. 5. Pp. 775-790. (In Eng.).

\section{References in Russian}

1. Авербух В.M. Шестой технологический уклад и перспективы России (краткий обзор) // Вестник Ставропольского государственного университета. 2010. № 71. C. $159-166$.

2. Аврорина Л. В. Россия: НКО как особый сегмент рынка социальных услуг // Вклад негосударственных некоммерческих организаций в решение социальных проблемы в России. Развитие социальных услуг: сб. ст. и материалов «мозгового штурма» / под ред. О. Б. Казакова. URL: http://www.civisbook.ru/ files/File/ngos_contribute.pdf (дата обращения: 07.09.2017).

3. Андреева M.E. Технологические уклады современной экономики. Электронное текстовое издание / науч. ред. С. В. Кортов. Екатеринбург, 2016.

4. Андрюшкевич О., Денисова И. Опыт функционирования предпринимательских университетов в контексте модели «тройной спирали». URL: http://kapital-rus.ru/articles/ article/opyt_formirovaniya_predprinimatelskih _universitetov_v_kontekste_modeli_troj/ (дата обращения: 21.04 .2017$)$.

5. Буняк Н. М. Предпринимательский университет: сущность и особенности формирования // Juvenis scientia. 2016. № 2. C. 144-147.

6. Демидов М. Новые возможности: что может дать бизнес вузам? URL: 4science.ru/articles/ Novaya-nisha-biznes-vusam (дата обращения: 01.09.2017).

7. Еферина Т. В., Лизунова В.О., Просянюк Д. В. Механизмы повышения качества социальных услуг: разгосударствление сферы социального обслуживания населения. URL: http://ac.gov.ru/files/content/1828/statyaeferina-lizunova-prosyanyuk-2-red-pdf.pdf (дата обращения: 09.09.2017).

8. Ефимов В. С., Лаптева А. В. Университет в ситуации постиндустриального перехода: глобальные тренды и вызовы развития. Университет 4.0. URL: www.slideshare.net/ leuter_of_strategic_RnD/40-68989423 (дата обращения: 09.09.2017). 
9. Ефимов В. С., Лаптева А. В. Когнитивный университет: контуры будущего // Университетское управление: практика и анализ. 2014. № 6(94). С. 18-29.

10. Жогин Б. Г. Конкуренция в сфере социальных услуг: преимущества и слабости НКО // Вклад негосударственных некоммерческих организаций в решение социальных проблемы в России. Развитие социальных услуг: сб. ст. и материалов «мозгового штурма» / под ред. О. Б. Казакова. URL: http://www.civisbook.ru/files/File/ngos_contribute.pdf (дата обращения: 07.09.2017).

11. Зайцев Д. В., Зайщева О. В. Разгосударствление социальной сферы в России: социальноправовой аспект // Общественные науки и современность. 2007. № 3. С. 174-176.

12. Ираева Н. Г., Калимуллина Э. Р. Особенности реализации инновационной деятельности в жилищно-коммунальном хозяйстве // Вестник УГНТУ. Наука, образование, экономика. Сер. Экономика. 2014. № 4. C. $42-45$.

13. Итоговый обзор по результатам участия преподавателей Санкт-Петербургского государственного экономического университета в ХX Петербургском международном экономическом форуме, 16-18 июня 2016 г. СПб., 2016. С. 17.

14. Кицай Ю. А. Правовое обеспечение конкурентоспособности негосударственных организаций в социальной сфере. М.: Изд. дом «БИБЛИО-ГЛОБУС», 2016. 240 с.

15. Кищай Ю. А. Некоммерческие организации исполнители общественно полезных услуг: мнение эксперта о проекте // Экономика. Предпринимательство. Окружающая среда. 2016. T. 2, № 66. C. 71-74.

16. Константинов Г.Н., Филонович С. Р. Что такое предпринимательский университет? // Вопросы образования. 2007. № 1. С. 49-63.

17. Кузнеиов E. Университет 3.0 в экономике знаний. URL: izvestia.ru/news/650622 (дата обращения: 09.09.2017).

18. Пономарев О.Б. К вопросу об управлении предпринимательской деятельностью // Вестник Балтийского федерального университета им. И. Канта. Сер. Гуманитарные и общественные науки. 2017. Вып. 2. С. 82-91.

19. Пушкина Н. Социальные услуги в исполнении НКО - ожидания и риски // https://www. asi.org.ru/article/2013/09/18/sotsial-ny-e-uslugiv-ispolnenii-nko-ozhidaniya-i-riski/ (дата обращения: 07.09.2017).

20. Серова О.А. Еще раз о государственных корпорациях или о новых задачах научных исследований // Вестник Пермского универ- ситета. Юридические науки. 2013. Вып. 4. C. 325-330.

21. Серова О. А. Право собственности публично-правовых компаний // Законы России: опыт, анализ, практика. 2017. № 2. С. 15-21.

22. Социальные предприниматели на рынке социальных услуг: перспективы развития. 2016. Вып. 2. 46 c. URL: http://www.socinvest.ru/wp-content/uploads/2017/04/Брошюpa-ФОМ.pdf (дата обращения: 06.09.2017).

23. Тихомиров А. В. Разгосударствление учреждений социальной сферы без приватизации закрепленного за ними имущества // Бизнес, менеджмент и право. 2009. № 3. С. 94-95.

24. Трифонов B. A. Приватизация как форма преобразования государственной собственности в современной российской экономике // Вестник КемГУ. 2014. № 1, т. 2. C. 235-240.

25. Феоктистова Е.Н. Развитие социального обслуживания с участием негосударственного сектора // Вклад негосударственных некоммерческих организаций в решение социальных проблемы в России. Развитие социальных услуг: сб. ст. и материалов «мозгового штурма» / под ред. О. Б. Казакова URL: http://www.civisbook.ru/files/File/ngos_contribute.pdf (дата обращения: 07.09.2017).

26. Хухлина В. В. Разгосударствление рынка социальных услуг в рамках реализации Ф3 № 442 «Об основах социального обслуживания граждан в Российской Федерации». URL: http://esa-conference.ru/wp-content/uploads/ files/pdf/Huhlina-Valentina-Vladimirovna.pdf (дата обращения: 06.09.2017).

27. Якушева $Ф$. Разгосударствление социальной сферы: первые шаги URL: http://rt-online.ru/ razgosudarstvlenie-sotsialnoj-sfery-pervye-shagi/ (дата обращения: 07.09.2017).

28. Broberg J. C., McKelvie A., Short J. C., Ketchen D. J. (jr.), Wan W. P Political institutional structure influences on innovative activity // Journal of Business Research. 2013. Vol. 66, issue 13. Pp. 2574-2580. DOI: 10.1016/j. jbusres.2012.05.014.

29. Christopher J. Governance Paradigms of Public Universities: an International Comparative Study // Tertiary Education and Management, Ifirst Article. 2012. 17 September. Pp. 1-17. DOI: 10.1080/13583883.2012.724705.

30. De Silva M. Academic Entrepreneurship and Traditional Academic Duties: Synergy or Rivalry? // Studies in Higher Education. 2015. 17 April Pp. 2169-2183. DOI: 10.1080/0307 5079.2015.1029901.

31. Hayter C.S. Harnessing university entrepreneurship for economic growth: Factors of suc- 
cess among university spin-offs // Economic development quarterly. 2013. Vol. 27. № 1. Pp. 18-28. DOI: 10.1177/0891242412471845.

32. Holloway K. J. Normalizing complaint: Scientists and the challenge of commercialization // Science, technology and human values. Cambridge (Mass.). 2015. Vol. 40. № 5. Pp. 744765. DOI: $10.1177 / 0162243915576004$.

33. Menzies M. B. Researching scientific entrepreneurship in New Zealand // Science and public policy. 2012. Vol. 39. Pp. 39-59. DOI: 10.31 52/030234212 X13214603531842.

34. Politis D., Gabrielsson J., Shveykina O. Earlystage finance and the role of external entrepreneurs in the commercialization of university-generated knowledge // Venture Capital.
2012. Vol. 14. № 2-3. Pp 75-198. DOI: 10.10 80/13691066.2012.667905.

35. Rooij A., van. University knowledge production and innovation: Getting a grip // Minerva. 2014. Vol. 52. № 2. Pp. 263-272. DOI: 10.1007/s 11024-014-9254-1.

36. Schejbal D. In search of a new paradigm for higher education // Innovative higher education OnlineFirst. 2012. 6 March. Pp. 1-14. DOI: 10.1007/s10755-012-9218-z.

37. Walsh E., Hargreaves C., Hillemann-Delaney U., Jizhen L. Doctoral researchers' views on entrepreneurship: Ranging from "a responsibility to improve the future" to "a dirty word" // Studies in higher education. 2015. Vol. 40, № 5. Pp. 775-790. 